\title{
Lipid Peroxidation and Ion Exudation of Pine Callus Tissues Inoculated with Pinewood Nematodes
}

\begin{abstract}
Hideaki IwAHORI* and Kazuyoshi FutaI*
The callus tissues of susceptible (Pinus parviflora) and resistant species of pine ( $P$. taeda) were inoculated with each of two isolates of Bursaphelenchus xylophilus (pathogenic and nonpathogenic) and one isolate of B. mucronatus (nonpathogenic). Changes in the amount of malondialdehyde (MDA), as an index of lipid peroxidation, and that of exuded ion were measured. On the callus tissue of $P$. parviflora, the amount of MDA increased only when a pathogenic nematode was inoculated, whereas on the callus tissue of $P$. taeda, the amount increased with the infection of any of the three isolates irrespective of its pathogenicity. Thus the callus tissues of $P$. parviflora responded in accordance with the pathogenicity of nematodes while that of $P$. taeda did not. Ion exudation from the callus tissue of $P$. taeda paralleled the pathogenicity of nematode isolate, whilst that from $P$. parviflora calli as almost the same with each of three isolates. Populations of each nematode isolate grew well on both species of pine callus tissues. However, on the callus tissue of $P$. parviflora, the rate of population increase until day six was far greater in the pathogenic isolate than nonpathogenic ones. In contrast, the rate on the callus tissue of $P$. taeda was almost the same among three isolates. Jpn.J.Nematol. 23: 79-89 (1993).

Key words: Bursaphelenchus xylophilus, lipid peroxidation, ion exudation, pine wilt disease, callus tissues
\end{abstract}

Innumerable pine stands in Japan have been seriously damaged by pine wilt disease caused by pinewood nematode (PWN), Bursaphelenchus xylophilus. The mechanism which triggers the development of the disease has not been well elucidated, though mechanisms leading to the obstruction of water conduction in the tracheid causing the trees to wither have been suggested.

In a series of studies on potato late blight caused by Phytophthora infestans, DokE $(4,5)$ have examined the mechanism of hypersensitive reaction (HSR) by comparing susceptible- and resistant-host responses to inoculation with compatible or incompatible races of the pathogen. They hypothesized that a superoxide anion-generating system is activated in potato tissues inoculated with the incompatible race. The generated superoxide anion triggers a sequence of resistance reactions resulting in hypersensitive cell death. Lipid peroxidation (3), the breakdown of membrane system (3), the loss of electrolytes from cells (15), and the loss of plasmolyzing ability (22) follow the generation of the superoxide anion.

YAMADA (23) measured the activity of superoxide dismutase (SOD) and the amount of malondialdehyde (MDA) of four-year-old Japanese black pine (Pinus thunbergii) seedling which had been inoculated with PWNs as indices of superoxide generation and lipid peroxidation, respectively. He found an increase in the amount of MDA after infection with PWNs, correlated

*Laboratory of Applied Botany, Faculty of Agriculture; Kyoto University, Kyoto, 606 Japan. 
with the proliferation of the nematode population, and concluded that the damage of cell membrane must be involved in the development of pine wilt disease.

As a causal mechanism of the pine wilt, we supposed progressive cell death due to the unsuccessful consequence of host resistant responses.

In the present research, pathogenic and nonpathogenic nematodes were inoculated to the callus tissues of susceptible and resistant pines. Lipid peroxidation and ion exudation from infected callus tissue were measured periodically to estimate the degree of disruption in the tissues' biomembrane, and to compare the host responses between pathogenic and nonpathogenic nematodes.

In this report, we designated the nematode isolate which can kill standing trees of susceptible pine species as pathogenic, and the isolate which can not as nonpathogenic. We also applied the word resistant/susceptible to the pine species whose standing trees, not callus tissues, are invulnerable/vulnerable to the infection of pathogenic nematodes.

\section{MATERIALS AND METHODS}

Callus cultures: The callus tissues of $P$. parviflora (susceptible pine) (7) and P. taeda (resistant pine) were cultured according to the method described by IWAHORI \& FUTAI (10). Briefly, seeds of these pines were surface sterilized with immersion in $30 \%$ hydrogen peroxide for one hour, rinsed three times with sterilized water, placed on $1 \%$ plain agar, and incubated under continuous light at $25^{\circ} \mathrm{C}$ until the cotyledons of seedlings were expanded. Seedlings were cut into several sections and placed on modified BROWN's medium (2), and then subcultured repeatedly by transferring to new medium once a month to proliferate the calli. These calli were transplanted into test tubes (18 $\mathrm{mm}$ dia., $105 \mathrm{~mm}$ long) containing $6 \mathrm{ml}$ of BROWN's medium. To minimize injurious effects during the transplanting procedure, the calli were kept for a week under the same conditions before use.

Preparation and inoculation of axenic nematode: Pathogenic (S1) and nonpathogenic isolates (S0) of B. xylophilus (PWN), and a nonpathogenic isolate $(\mathrm{M})$ of $B$. mucronatus were subcultured on Botrytis cinerea grown on the autoclaved grains of barley. Seven to ten days before the commencement of the experiment, they were transferred onto the new cultures of $B$. cinerea (grown on potato dextrose agar) and proliferated at $25^{\circ} \mathrm{C}$. Nematodes were separated from the hyphae of $B$. cinerea using the preautoclaved apparatus shown in Fig. 1.

An equal volume of sterilized water ( $c a .10$ $\mathrm{ml}$ ) was poured into the flask of nematode culture, then shaken. The resulting nematode suspension was then poured into a stainless steel

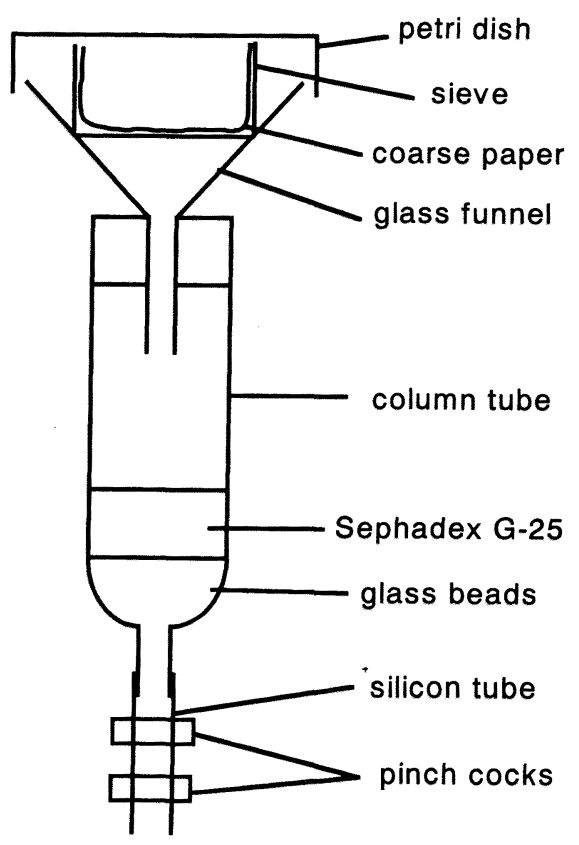

Fig. 1 The apparatus used for separating sterilized nematodes from monoxenic culture reared on the fungus of Botrytis cinerea. 
sieve covered with four sheets of coarse paper. After 24 hours, the axenic nematodes concentrated in the bottom of silicone tube were recovered.

The suspension of recovered nematodes was centrifuged for a minute at 2,500 r.p.m., and the supernatant was discarded to remove any fungal hyphae present. This operation was repeated five times. Final nematode density in suspension was adjusted to $c a$. 1,000 nematodes $/ \mathrm{ml}$. A 0.1 $\mathrm{ml}$ aliquot of the nematode suspension (containing $c a .100$ nematodes) was pipetted onto the callus tissue in each test tube. Both the inoculated callus cultures and non-inoculated controls were incubated under continuous light at $28^{\circ} \mathrm{C}$.

Measurements: Callus tissue of $P$. parviflora and $P$. taeda were inoculated with one of the three nematode isolates. Thirty callus tissues of both pine species received no nematode and served as control. On 2, 4, 6, 8, 10, and 12 days after inoculation, five callus tissues were randomly selected from each pine callus-nematode isolate combination, and from the controls of both pine species and served following measurements.

(1) Lipid peroxidation: The level of lipid peroxidation in the callus tissues was determined in terms of malondialdehyde (MDA) content by the method of HEATH \& PACKER (8) with minor modification as follows. Each callus was weighed, immersed in $5 \mathrm{ml}$ of $0.1 \%$ trichloroacetic acid (TCA), and homogenized with glass homogenizer for 30 seconds. Then resulting solution was filtrated through filter paper (Toyo No. 2). Four milliliter of $0.5 \%$ thiobarbituric acid in $20 \%$ TCA was added to $1 \mathrm{ml}$ of the filtrate, and then boiled for 30 minutes. After cooling in running tap water, the absorbance of the reaction mixture was measured at $532 \mathrm{~nm}$ and $600 \mathrm{~nm}$ with a spectrophotometer (Shimadzu, UV-100-02). The value of absorbance at $600 \mathrm{~nm}$ (non-specific absorption) was subtracted from that at $532 \mathrm{~nm}$ (absorption peak of MDA) and the remainder was used as the index of amount of peroxidized lipid in the callus tissue (8).

(2) Ion exudation: After weighing, each callus was transferred into a stainless steel cage $(20 \times 20 \times 20 \mathrm{~mm})$, rinsed in running tap water for 15 minutes to wash out ionic substances from the surface of the callus, and from injured cells, and immersed in distilled water for 5 minutes to remove the ionic substances derived from tap water. Each callus was then kept in $10 \mathrm{ml}$ of distilled water for 10 minutes with intermittent gentle shaking, and filtrated through a glass filter (SibAtA, cylindrical funnel type, 3G1). The electric conductance of the resulting filtrate was determined with an electric conductivity meter (M \& S Instruments Inc., CD-35MII). This value ( $\mu \mathrm{mho}$ ) gave an index of the amount of ions exuded from the callus tissues.

(3) Nematode population: After weighing each callus, nematodes were separated from the callus tissue using a modified BAERMAN funnel (Fig. 2). Each callus was placed in the funnel, and ca. $10 \mathrm{ml}$ of distilled water was poured on it, and kept still over night. Nematodes collected at the bottom of glass tube were recovered and counted.

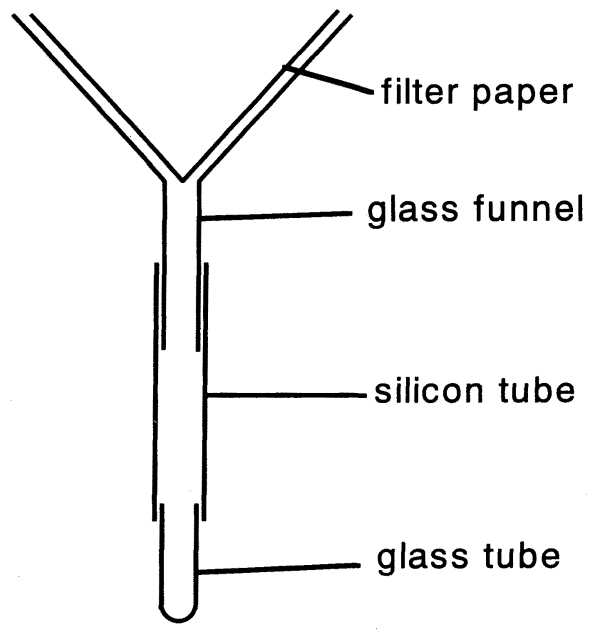

Fig. 2 The apparatus used for recovering nematodes from callus tissues. 

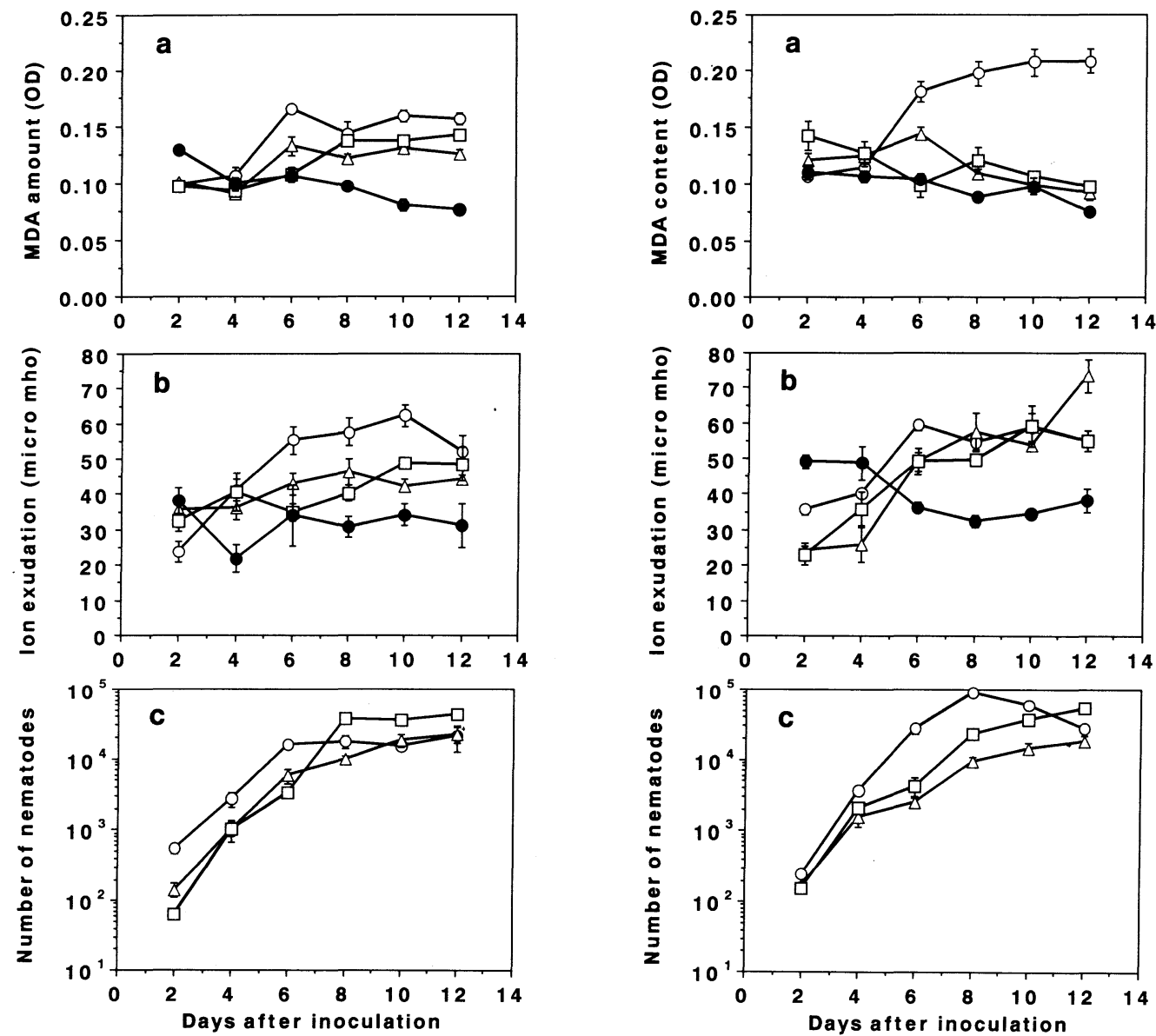

Fig. 3 Changes in (a) MDA amount, (b) ion exudation from the callus tissues of $P$. taeda inoculated with either of three nematode isolates; S1 $(\bigcirc)$, S0 $(\triangle)$ and $\mathrm{M}$ ( $\square$ ) or from non-inoculated controls (O), and (c) changes in the population of each isolate of nematode. Vertical bars represent standard errors.

Fig. 4 Changes in (a) MDA amount, (b) ion exudation from the callus tissues of $P$. parviflora inoculated with either of three nematode isolates; $\mathrm{S} 1(\bigcirc)$, S0 $(\triangle)$ and $\mathrm{M}$ ( $\square$ ) or from non-inoculated controls (O), and (c) changes in the population of each isolate of nematode. Vertical bars represent standard errors.

When necessary, the nematode suspension was diluted between 5 to 200 times for counting.

Analysis of correlation: Correlation coefficients were calculated and simple regression analysis was conducted to examine the correlations between the number of nematodes, and the amounts of MDA and exuded ion.

\section{RESULTS}

Lipid peroxidation: Following nematode inoculation the MDA amount of $P$. taeda calli increased irrespective of the nematode isolate inoculated $(p=0.01)$. The final level of MDA (on day 12) was highest in the calli which received the pathogenic S1 isolate, followed by those inoculated with isolate $\mathrm{M}$, with the lowest levels found in those inoculated with isolate S0. The amount of MDA in non-inoculated calli decreased gradually (Fig. 3a). However, the amount of MDA increased markedly $(p=0.01)$ in the calli of $P$. parviflora that received the pathogenic S1 
isolate. In contrast, the amount of MDA in S0or $\mathrm{M}$-inoculated callus tissues decreased with time in the same way as the controls (Fig. 4a). Thus the host response of calli shown in lipid peroxidation reflected the difference in nematode pathogenicity. This effect was stronger in $P$. parviflora than in P. taeda.

Ion exudation: As shown in Fig. $3 \mathrm{~b}$ the amount of ion exuded from callus tissue of $P$. taeda increased with time. The degree of increased ion exudation from $P$. taeda calli was most prominent when the calli were inoculated with the S1 isolate. No increase was observed on non-inoculated controls. On day 12 after inoculation, the amount of ion exuded was highest on S1-inoculated calli, followed by those inoculated with $\mathrm{M}$ or S0 isolate, and then the noninoculated controls. Thus, the change in the amount of ions exuded after nematode inoculation was similar to the changes in the amount of MDA. The degree of ion exudation seemed to correspond to the pathogenicity of nematode.

In contrast, the ion exuded from the callus tissue of $P$. parviflora again increased with time after nematode inoculation, a gradual decrease was found in the non-inoculated controls. There was no difference in the quantity of ions exuded between the callus tissues inoculated with the different nematode isolates (Fig. $4 \mathrm{~b}$ ). This contrasts with the above mentioned results where the MDA content of $P$. parviflora calli increased only when inoculated with the S1 isolate.

Nematode propagation: During the six days after the inoculation, the populations of all the nematode isolates grew exponentially on both $P$. taeda and $P$. parviflora callus tissues (Fig. 3c, 4c). Logarithmic values of nematode number on day 2, 4 and 6 were linearly regressed, and the slope of the regression line was calculated as the rate of population growth (Table 1). On P. taeda calli, populations of all three isolates increased at similar rates. On P. parviflora calli, however, the population growth rate was markedly higher in the S1 isolate than in the M or S0 isolate. Callus tissues of both pine species began to brown by day six, irrespective of the isolate inoculated.

Correlation among the number of nematode, the amount of $M D A$ and that of exuded ion: To examine the relationship between any two of the three variables (the logarithmic value of nematode number, the amount of MDA, and the amount of exuded ion), simple regression analysis was carried out. Overall, correlation coefficients and regression lines (Table 2) calculated for each combination of the two variables suggest that the calli that had received nematodes of the $\mathrm{S} 0$ or $\mathrm{M}$ isolate responded similarly, whereas those inoculated with the S1 isolate responded differently. The exception to this was the correlation between the amount of ions exuded from $P$. parviflora calli and the logarithmic values of nematode density (Fig. 6b).

(1) Correlation between the number of nematode and the amount of MDA: When the calli of either pine species received nematodes of S1 isolate, the MDA amount markedly increased with increasing nematode population. In contrast in calli inoculated with $\mathrm{S} 0$ or $\mathrm{M}$ isolate, there was again a positive correlation in $P$. taeda but a negative one in $P$. parviflora (Figs. 5a, 5b). 
Table 2 The slopes (a) and intercepts (b) of simple regression lines and correration coefficients ( $r$ )

a. between number of nematodes and MDA content

\begin{tabular}{ccrrr}
\hline Pine Species & $\begin{array}{c}\text { Nematode } \\
\text { isolates }\end{array}$ & \multicolumn{1}{c}{ Slopes } & Intercept & \multicolumn{1}{c}{$\mathrm{r}$} \\
\hline \multirow{3}{*}{ P. taeda } & S1 & -0.0225 & 0.0417 & $0.93^{* *}$ \\
& S0 & 0.0596 & 0.0161 & $0.81^{*}$ \\
& M & 0.0551 & 0.0174 & $0.90^{* *}$ \\
\hline \multirow{3}{*}{ P. parviflora } & S1 & -0.0137 & 0.0445 & $0.91^{*}$ \\
& S0 & 0.1657 & -0.0144 & -0.59 \\
& M & 0.1695 & -0.0143 & -0.78 \\
\hline
\end{tabular}

b. between number of nematodes and ion exudation

\begin{tabular}{ccrrl}
\hline Pine Species & $\begin{array}{c}\text { Nematode } \\
\text { isolates }\end{array}$ & \multicolumn{1}{c}{ Slopes } & Intercept & \multicolumn{1}{c}{$\mathrm{r}$} \\
\hline \multirow{3}{*}{ P. taeda } & S1 & -32.9120 & 21.1607 & $0.95^{* *}$ \\
& S0 & 24.9181 & 4.5488 & $0.87^{*}$ \\
& M & 23.6978 & 4.6941 & 0.80 \\
\hline \multirow{3}{*}{ P. parviflora } & S1 & 10.9456 & 9.6615 & $0.92^{* *}$ \\
& S0 & -30.1233 & 21.8878 & $0.88^{*}$ \\
& M & -6.0608 & 13.5161 & $0.96^{* *}$ \\
\hline
\end{tabular}

c. between MDA content and ion exudation

\begin{tabular}{ccrrc}
\hline Pine Species & $\begin{array}{c}\text { Nematode } \\
\text { isolates }\end{array}$ & Slopes & Intercept & \multicolumn{1}{c}{$\mathrm{r}$} \\
\hline \multirow{4}{*}{ P. taeda } & S1 & -11.7326 & 436.4886 & $0.89^{*}$ \\
& S0 & 15.3405 & 220.3727 & $0.85^{*}$ \\
& M & 13.1080 & 233.9891 & 0.77 \\
P. parviflora & C & 21.9945 & 99.1743 & 0.34 \\
& S1 & 16.5040 & 201.7246 & $0.94^{* *}$ \\
& S0 & 112.6411 & -569.2111 & -0.56 \\
& M & 123.8023 & -680.6978 & $-0.88^{*}$ \\
& C & 8.7985 & 319.1621 & 0.57 \\
\hline
\end{tabular}

Significance level: ${ }^{* *} 0.01$ and ${ }^{*} 0.05$

(2) Correlation between the number of nematodes and the amount of exuded ion: The relationship of the nematode population with the amount of ion exuded from the callus tissues of $P$. taeda was similar to the relationship with MDA concentration (Fig. 6a). When the callus tissues of $P$. parviflora were inoculated, however, the degree of ion exudation rose equally with increase in nematode population (Fig. 6b) irrespective of the nematode isolate inoculated.

(3) Correlation between the amount of MDA and that of exuded ion: On the callus tissue of $P$. taeda, the amount of exuded ion increased according to the increase in MDA amount irrespective of the isolate of nematodes inoculated (Fig. 7a). On the P. parviflora calli, however, a positive correlation was observed only when the callus tissue received $\mathrm{S} 1$ isolate. When the callus tissues received $\mathrm{S} 0$ or $\mathrm{M}$ isolate, the correlation become negative, though not significant in the combination with S0 isolate (Fig. 7b). On the controls (non-inoculated callus tissues), no significant correlation was observed on either P. taeda or on P. parviflora callus tissue (Table 2c). 

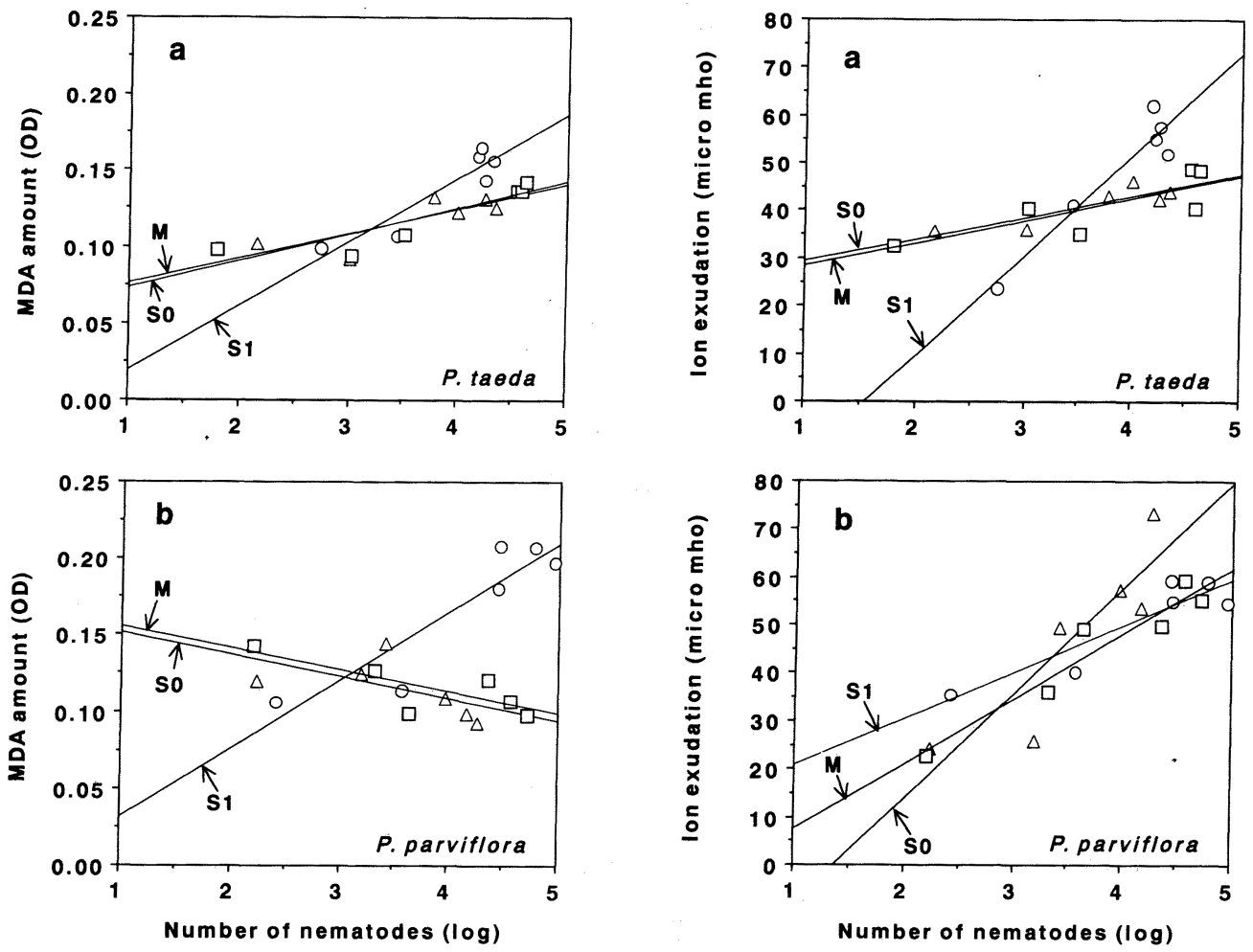

Fig. 5 The relationship between the number of nematodes of either of three isolates; S1 $(\bigcirc)$, S0 $(\triangle)$ and $\mathrm{M}(\square)$ and the amount of MDA from the callus tissues infected. (See Table 2 for the values of slopes of respective regression lines, and correlation coefficients.)

Fig. 6 The relationship between the number of nematodes of either of three isolates; S1 $(\bigcirc)$, S0 $(\triangle)$ and $M(\square)$ and the amount of ion exuded from the callus tissues infected. (See Table 2 for the values of slopes of respective regression lines, and correlation coefficients.)

\section{DISCUSSION}

Sudden death of pine trees by pine wilt disease has been attributed to the obstruction of water flow through xylem tracheids. In examining the mechanism of the obstruction of water flow, KURODA (12) found an increase in volatile terpenes long before the occurrence of cavitation in the tracheids, and hypothesized that the excessive production of the terpene volatiles can promote tracheid cavitation and thereby wither pine trees. NoBUCHI et al. (16) reported that vacuoles developed after the inoculation of PWN in parenchyma cells of $P$. thunbergii seedlings. These vacuoles subsequently burst resulting in necrosis of the cells. Unidentified substances released from these necrotic cells cover the pit membrane and therefore lower water conductivity through tracheids. Concerning the causal mechanisms of disease development, alternate candidates such as water stress (21), cellulase (17) and phytotoxins (19) have also been proposed, and reviewed by Suzuki (20).

To explain quick death of pine trees by PWN, we assumed a falling-domino effect as follows ; superoxide anion is generated as the first step of a built-in defence system in response to PWN infection. The anion then cause lipid peroxidation resulting in deterioration of biomem- 
brane. Cell contents from collapsed cells would then be released into the sap flow through tracheids covering the pit membrane. The sap flow is thereby obstructed. Based on this idea we studied the very first phase of pine wilt disease using callus tissues.

It has been often pointed out that the use of callus tissues to study the interaction between plant hosts and pathogens includes some potential (and even real) problems due to its denatured property (9). However contrary results to this have also been reported, where the callus tissue of alfalfa responded to the infection of Verticillium albo-atrum in a manner corresponding to the susceptibility of the respective mother plants (11).

Amongst the various defensive reactions of plants, only dynamic reactions can be studied with callus tissues, whereas static defensive barriers and defenses that are built as a result of intercellular communication may be impossible to examine (9). In our previous research (10), we examined interactions of plant calli and nematodes by comparing 10-combinations (2 nematode isolates $\times 5$ pine species), and found differences in population growth rate of the
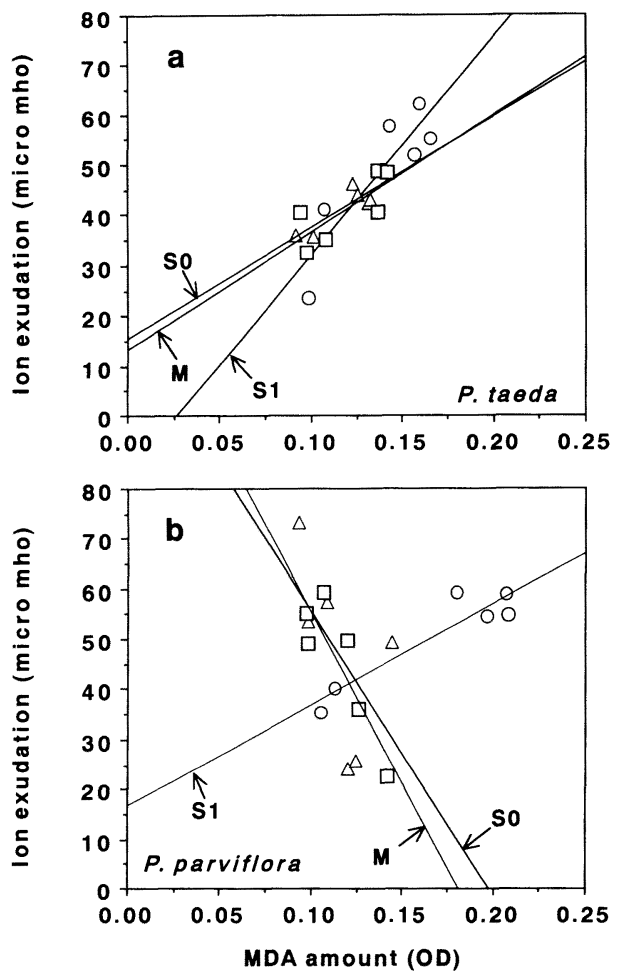

Fig. 7 The relationship between the the amount of MDA and that of ion exuded from the callus tissues infected with either of three nematode isolates; $\mathrm{S} 1(\bigcirc)$, S0 $(\triangle)$ and $\mathrm{M}$ ( $\square$ ). (See Table 2 for the values of slopes of respective regression lines, and correlation coefficients.) nematodes, their saturation density, and the tannin amount of callus tissues challenged by the nematodes. The increase in tannin, however, seemed to be rather late response, and some other biochemical defenses were expected to occur previous to this increase in tannin.

A universal dynamic resistant response of plants to fungi, bacteria, viruses, and nematodes is the quick death of infected cell(s), which become darkly pigmented, designated as HSR. MYERS (14) believes that the HSR in pines, which successfully control most pathogens, is responsible for their ultimate death after inoculation by PWN. He hypothesized that PWN defeat this innate defense mechanism by moving rapidly through the pine tissues and continually triggering the HSR. Coalescing zones of dying tissues release oleoresins, polyphenols, and toxins, ultimately creating an area of excessive blockage of the water-conducting tracheids.

HSR starts with an increase in the activity of oxidative enzymes (13), resulting in the generation of superoxide which may attack unsaturated fatty acids to produce peroxidized lipids. The semi-permeability of the cell membrane may be damaged by this peroxidation of the lipids, and therefore the cell contents may leak out of the infected tissues.

On the basis of MYERs' hypothesis we measured amount of MDA and electrical conductance of aqueous filtrate of each callus as indices of lipid peroxidation, and leakage of cell contents, 
respectively.

The present study revealed different interactions between calli receiving pathogenic nematodes ( $\mathrm{S} 1)$ from those receiving nonpathogenic ( $\mathrm{S} 0$ and $\mathrm{M}$ ) isolates. The responses of the callus tissues derived from susceptible and resistant pine species also differed. Generally, the host responses found on calli inoculated with the S0 isolate were similar to those calli received $\mathrm{M}$ isolate, even though these two isolates belong to different nematode species.

As far as the production of peroxidized lipid is concerned, the callus tissue of $P$. parviflora seemed to respond in parallel with the pathogenicity of nematode isolate inoculated. The higher the pathogenicity of the nematode isolate, the stronger the host response. This agrees well with MYERS' hypothesis, which supposes excessive HSR is responsible for ultimate death of pine trees. On the contrary, callus tissues of $P$. taeda responded almost equally to the three isolates of nematodes irrespective of their pathogenicity; the amount of MDA was kept at a relatively high level with progress of tissue necrosis until the end of experiment in each case. This seems to be inconsistent with MYERS' hypothesis, because sequential lipid peroxidation was observed in the callus of $P$. taeda despite its mother plant's resistance to PWN. Therefore another mechanism is necessary to account for the resistance of $P$. taeda. The resistance could be attributed to the toxic substance contained in aqueous extracts of pine tissue (6). Toxicity has been shown to be higher in the resistant $P$. taeda than in the susceptible $P$. densiflora. This substance displayed high activity in immobilizing PWN, so it is reasonable to assume that this substance arrests the movement of PWN away from the area of necrosis (1). As suggested by MYERS (14), the mobility of nematode inside the tree seems to be responsible for expressing its pathogenicity. Some experiments conducted on nematode's mobility showed that migration ability was greater in pathogenic B. xylophilus than in nonpathogenic B. mucronatus (18). Similar experiments with nonpathogenic isolate of $B$. xylophilus are needed to confirm the importance of nematode mobility in determining its pathogenicity.

On the callus tissues of $P$. taeda, more electrolyte exuded when it was inoculated with a more pathogenic isolate. Therefore the amount of exuded ion paralleled that of MDA and lipid peroxidation seems to have caused the deterioration of biomembrane with the resulting ion exudation. On the callus tissues of $P$. parviflora, however, inoculation with nematodes caused exudation of similar amount of ions irrespective of nematode isolate. A causal factor other than lipid peroxidation must therefore be involved in ion exudation from $P$. parviflora callus tissues.

In combinations such as $P$. taeda calli and each of three nematode isolates, and $P$. parviflora calli and the S1 isolate, the intensity of ion exudation correlated positively to the amount of MDA (Figs. 7a, 7b, Table 2c). However, this brings about quite opposite results to the two pine species, death in $P$. parviflora, and successful defence in $P$. taeda. In combinations between $P$. parviflora calli and $\mathrm{S} 0$ or $\mathrm{M}$ isolate, however, ion exudation and the amount of MDA correlated negatively with each other (Figs. 7a, 7b, Table 2c).

Based on the results obtained from present experiments and ones from other reports $(1,6$, 18), the following mechanisms were suggested to distinguish the susceptible responses of $P$. parviflora from the resistant ones of $P$. taeda to the infection of PWN occurring in the field: (a) In $P$. parviflora, the reaction of host tissues, which is evoked only when infected with pathogenic isolate of nematodes, and their incapability of arresting nematodes at the necrotic area causes this species to be susceptible. (b) The standing trees of $P$. taeda display resistance against the 
inoculation of PWNs regardless of their pathogenicity, though the reaction of the calli seems to be ineffective in suppressing the nematodes' propagation. The unknown substance(s) contained in the tree tissues immobilize nematodes and/or prevent their reproduction, thereby restricting their activity to the area of the infection site. In this way $P$. taeda seems to achieve its resistance against the infection of PWN.

A similarity in host responses was found between the calli receiving nonpathogenic isolate of B. xylophilus $(\mathrm{S} 0)$ and those received an isolate of B. mucronatus (M). As mentioned above, callus tissue seems to recognize the difference in pathogenicity of nematodes in some way, and is therefore very useful in the investigation of the very early stages of pine wilt disease.

\section{ACKNOWLEDGEMENT}

The authors thank to Dr. M. BooTs, University of Liverpool, for his critical reading of this manuscript.

\section{LITERATURE CITED}

1) Bentley, M. D., Mamiya, Y., Yatagai, M. \& Shimizu, K. (1985) Factors in Pinus species affecting the mobility of the pine wood nematode, Bursaphelenchus xylophilus. Ann. Phytopath. Soc. Japan 51, 556-561.

2 ) Brown, C. L. (1968) Culture of pine callus on a defined medium. Forest Sci. 14, 62-64.

3 ) Dhindsa, R. S., Plumb-Dhindsa, P. \& Thorpe, T. A. (1981) Leaf senescence: correlated with increased levels of membrane permeability and lipid peroxidation, and decreased levels of superoxide dismutase and catalase. J. Exp. Bot. 126, 93-101.

4 ) DoKe, N. (1983) Involvement of superoxide anion generation in the hypersensitive response of potato tuber tissues to infection with an incompatible race of Phytophthora infestans and to the hyphal wall components. Physiol. Plant Pathol. 23, 345-357

5 ) Doke, N. (1983) Generation of superoxide anion by potato tuber protoplasts during the hypersensitive response to hyphal wall components of Phytophthora infestans and specific inhibition of the reaction by suppressors of hypersensitivity. Physiol. Plant Pathol. 23, 359-367.

6 ) FUTAI, K. (1979) Responses of two species of Bursaphelenchus to the extracts from pine segments and segments immersed in different solvents. Jpn. J. Nematol. 9, 54-59.

7 ) Futai, K. \& Furuno, T. (1979) The variety of resistances among pine-species to pine wood nematode, Bursaphelenchus lignicolus. Bull. Kyoto Univ. For. 51, 23-36. (In Japanese with English summary)

8 ) HeAth, R. L. \& PACKer, L. (1968) Photoperoxidation in isolated chloroplasts. I. Kinetics and stoichiometry of fatty acid peroxidation. Arch. Biochem. Biophys. 125, 189-198.

9 ) Helgeson, J. P. (1983) Studies of host-pathogen interaction in vitro. In: Use of Tissue Culture and Protoplasts in Plant Pathology (Helgeson, J. P. \& Deverall, B. J., eds.), Academic Press, Sydney, 9-38.

10) Imahori, H. \& Futai, K. (1990) Propagation and effects of the pinewood nematode on calli of various plants. Jpn. J. Nematol. 20, 25-36.

11) KoIKe, M. \& SHImada, T. (1992) Alfalfa-Verticillium albo-atrum interactions: II. in vitro peroxidase and phenylalanine ammonialyase activities enhanced by treatment with fungal elicitors. Plant Tissue Culture Letters $\mathbf{9}, 81-85$.

12) KuRODA, K. (1991) Mechanism of cavitation development on the pine wilt disease. Eur. J. For. Path. 21, 82-89.

13) Muller, K. O. (1959) Hypersensitivity. In: Plant Pathology (Horsfall, J. G. \& Dimond, A. E., eds.), Academic Press, New York, 469-519.

14) Myers, R. F. (1988) Pathogenesis in pine wilt caused by pinewood nematode, Bursaphelenchus 
xylophilus. J. Nematol. 20, 236-244.

15) Nishimura, N., Tomiyama, K. \& Doke, N. (1981) Effect of infection by Phytophthora infestans and treatment with zoosporial water-insoluble components on leakage of ${ }^{86} \mathrm{Rb}^{+}$from potato tuber cells. Ann. Phytopath. Soc. Japan 47, 308-312.

16) Nobuchi, T., Tominaga, T., Futai, K. \& Harada, H. (1984) Cytological study of pathological changes in Japanese black pine (Pinus thunbergii) seedlings after inoculation with pine-wood nematode (Bursaphelenchus xylophilus). Bull. Kyoto Univ. For. 56, 224-233.

17) Odani, K., Sasaki, S., Nishiyama, Y. \& Yamamoto, N. (1985) Early symptom development of the pine wilt disease by hydrolytic enzymes produced by the pine wood nematodes-cellulase as a possible candidate of the pathogen. J. Jap. For. Soc. 67, 366-372.

18) Odani, K., Sasaki, S., Yamamoto, N., Nishiyama, Y. \& Tamura, H. (1985) Differences in dispersal and multiplication of two associated nematodes, Bursaphelenchus xylophilus and Bursaphelenchus mucronatus in pine seedlings in relation to the pine wilt disease development. J. Jap. For. Soc. 67, 398-403.

19) Oкu, H. (1988) Role of phytotoxin in pine wilt disease. J. Nematol. 20, 245-251.

20) SuzuKI, K. (1992) Mechanism of pine wilt in the pine wilt disease. Forest Pests 41, 59-64. (in Japanese)

21) Suzuki, K. \& Kiyohara, T. (1978) Influence of water stress on development of pine wilting disease caused by Bursaphelenchus xylophilus. Eur. J. For. Path. 8, 97-107.

22) Tomiyama, K. (1976) Further observations on the time requirement for hypersensitive cell death of potatoes infected by Phytophthora infestans and its relation to metabolic activity. Phytopathol. Z. 58, 367-373.

23) Yamada, T. (1987) Lipid peroxidation during the development of pine wilt disease. Ann. Phytopath. Soc. Japan 53, 523-530.

Accepted for publication: September 7, 1993.

\title{
和文摘要
}

\section{マツノザイセンチュウを接種したカルス組織における 脂質過酸化とイオン漏出}

\author{
岩堀 英晶・二井 一禎
}

感受性のヒメコマツ及び抵抗性のテーダマツのカルス組織にマツノザイセンチュウの病原性系統及 び非病原性系統並びに非病原性系統のニセマツノザイセンチュウを接種し、カルス組織とこれら線虫 系統間の相互作用を比較調査した。その結果、これら線虫の系統の違いにより、また 2 種のマツカル ス組織の間で、脂質過酸化の程度、イオン漏出、線虫増殖率に差が見られた。また、カルス組織は線 虫の病原性の違いに応じた反応を示し、非病原性の 2 系統の線虫接種に対しては、それらの線虫が異 なった種に属するにも関わらず類似した反応を示した。 